\title{
First Efforts in Benchmarking the Stoker/Pulverized Coal Industry
}

\author{
Jack Fuller $^{*}, 1$ and Matthew Robinson ${ }^{2}$ \\ ${ }^{I}$ Department of Management, West Virginia University, Morgantown, WV 26505-6025, USA \\ ${ }^{2}$ Department of Mechanical and Aerospace Engineering, West Virginia University, Morgantown, WV 26505-6025, USA
}

\begin{abstract}
Environmental impact of the coal-fired, electrical power industry has led to increased regulatory requirements. For the industry to remain relevant, it is paramount that it maintains a trajectory of progress towards higher efficiencies and cleaner emissions. Research and development might lead to new technologies, but in the meantime, improvement of existing technology must also be a focus. One method being pursued for this is a benchmark study which can identify best practices and areas where performance might be improved. Over the last decade, the Council of Industrial Boiler Owners and certain faculty at West Virginia University have worked together to collect survey data from atmospheric fluidized bed combustion boiler industry members. However, this accounts for only a small portion of the total coal-fired, electrical power industry $(\sim 2 \%)$. On the other hand, stoker/pulverized coal boiler operation accounts for most of the industry production ( $\sim 92 \%)$. This report gives the data gathered from stoker/pulverized coal industry members for the operational year 2012. From the applied survey methods, the resulting data pool was small due to a small number of respondents. In the future it is important that the number of survey respondents increases to better reflect the industry and allow more successful benchmarking of the industry. For this initial effort, comparisons are made against recent fluidized bed combustion data to show that, for the given survey responses, stoker/pulverized coal boilers operated at a lower average calcium/sulfur ratio, higher average efficiency, and on average, required more non-management staff per gross MW. This study and comparison serves to provide a good starting point for efforts in benchmarking the stoker/pulverized coal industry.
\end{abstract}

Keywords: Benchmarking, coal-fired power plants, power generation, pulverized coal, stoker.

\section{INTRODUCTION}

In 2012, coal fired boilers accounted for the largest share, $37 \%$, of total electricity generation throughout the United States [1]. This trend is predicted to continue until around the year 2035 when natural gas gains ground in the industry, but coal will retain a high share of the market. It maintains its lead in the market because of its abundance as a mineable fossil fuel as well as its extensive integration into U.S. infrastructure. However, coal related emissions have long been a difficulty for the industry. Because of the high carbon content in coal, power plants burning coal have the highest output of $\mathrm{CO}_{2}$ per kWh. Also, Mercury and Air Toxic Standards (MATS) compliance will likely require update and installation of new systems for nearly half of the coal fired generator industry. These strains, and others including the difficulty of obtaining coal and competition from other fuel sources, are resulting in the retirement of older generator units. It is projected that $50 \mathrm{GW}$ of capacity - representing about $1 / 6^{\text {th }}$ of the current industry - will be retired through 2020 [2]. To maintain competitiveness, coal fired generators must advance towards greater efficiency and fewer harmful emissions.

This might be accomplished in a number of ways, but aside from emerging clean coal technologies which are not

*Address correspondence to this author at the Department of Management, West Virginia University, Morgantown, WV 26505-6025, USA;

Tel: 304-293-7935; E-mail: Jack.Fuller@mail.wvu.edu read to be deployed on larger scales, continuing to improve the efficiency and reducing harmful emissions from existing technologies can have a positive impact. Over the last twelve years, researchers at West Virginia University (WVU), working with the Council of Industrial Boiler Owners (CIBO), have been gathering survey data for the purpose of forming industry benchmarks to aid in the continuous improvement effort of the coal-fired industry. Past surveys have focused specifically on atmospheric fluidized bed combustion (AFBC) units. (Examples of these study results can be seen in Fuller publications [3, 4]). However, these only account for a small percent of the coal industry (about $2 \%$ in 2008). Another $6 \%$ of total coal consumed in the industry goes to cyclone boilers, and by far the largest portion of the market is consumed by pulverized coal combustion (PC) and stoker boilers (approximately 92\%) [5]. These statistics bring to light the importance of continuing to advance the art of stoker/PC boiler operation. This report gives the results of the 2012 benchmark survey data gathered from operators of stoker and pulverized coal type boiler units.

\section{STOKER BOILERS}

Stoker fired coal combustion is the oldest boiler technology but is used minimally within the industry. During operation, lumped coal is fed onto a grate by a mechanical device called a "stoker". Combustion inefficiencies largely contribute to the inability of stokers to compete with more modern technologies leading to a steady decline in service in 
the United States [5]. As stoker technology is retired, it is being replaced by atmospheric fluidized bed combustion, cyclone, and, most substantially, pulverized coal combustion boilers.

\section{PULVERIZED COAL BOILERS}

Pulverized coal (PC) combustion boilers are considered a conventional technology, but they maintain a substantial portion of the market. In operation, coal is crushed into a fine powder and blown into a furnace chamber along with preheated combustion gases. The resulting combustion is used to create steam which is then used to generate electrical power in a steam turbine, Rankine cycle.

Common products of the process, including gaseous emissions, are ash (unburnt minerals and carbon), water, $\mathrm{NO}_{\mathrm{x}}, \mathrm{SO}_{2}$, some heavy metals including mercury $(\mathrm{Hg})$, arsenic (As), chromium $(\mathrm{Cr})$, and nickel $(\mathrm{Ni})$, and the commonly recognized greenhouse gas, $\mathrm{CO}_{2}$ [6]. Ash can serve further purpose in other industries such as construction and highway maintenance and is often sold [7, 8]. Emissions of $\mathrm{NO}_{\mathrm{x}}, \mathrm{SO}_{2}$, heavy metals, and $\mathrm{CO}_{2}$ are subject to tightening EPA regulations and must be dealt with accordingly.

\section{EMISSIONS REGULATIONS}

To reduce emissions of sulfur dioxide $\left(\mathrm{SO}_{2}\right)$ and nitrogen oxides $\left(\mathrm{NO}_{\mathrm{x}}\right)$ from power plants, cap and trade programs have been implemented by the Environmental Protection Agency. These programs, the Clean Air Interstate Rule (CAIR) and the Acid Rain Program (ARP), are seeing near perfect power plant compliance. From 2005 to 2011, they are responsible for $56 \%$ reduction in $\mathrm{SO}_{2}$ emissions and $46 \%$ reduction in $\mathrm{NO}_{\mathrm{x}}$ emissions [9]. Greenhouse gas (GHG) emissions standards are currently being addressed by government officials [10], and heavy metals, specifically mercury, are restricted under the Mercury and Air Toxics Standards (MATS) for Power Plants [11]. Because GHG and MATS regulations are new and future implementations, reported survey data deals only with emissions of $\mathrm{SO}_{2}$ and $\mathrm{NO}_{\mathrm{x}}$.

\section{BENCHMARKING}

Benchmarking has been proven as a successful method to improve the performance of various industries. By identifying best practices and setting performance standards, industry members are able to maintain stronger methods and strengthen weaker ones. Investigations have shown that organizations who partake in benchmarking practices tend to outperform their peers [12]. The continued efforts of the Council of Industrial Boiler Owners (CIBO) and researchers at West Virginia University (WVU) to benchmark the coal fueled power plant industry have served to provide performance standards for atmospheric fluidized bed combustion (AFBC) boiler operators. This effort is now being expanded to include the much larger portion of the industry: stoker/PC boilers.

\section{THE SURVEY}

Between February 15 and May 1 of 2013, a survey was administered via web site and direct email contact between WVU researchers, CIBO members, and volunteer boiler owner participants. Once the surveys were completed by the participants, they were submitted electronically. Participants were managers of industrial power plant facilities which produce electricity or steam for industrial use. Many of these individuals were identified through their membership in the Council of Industrial Boiler Owners (CIBO) or though other available databases. Through a detailed check on survey respondents, the sponsoring organization determined that the sample could be considered to be representative of the population at large.

The 2012 data produced by the survey was fully voluntary and focused on five areas: plant information, fuel information, efficiency and environmental performance, research and development, and plant operations. The survey then more specifically breaks down outage causes and future concerns. The data produced by the survey were analyzed using standard statistical techniques.

\section{Plant Information}

This section gathers general boiler and operational information including a breakdown of the staff by number of full-time (FT) operations, maintenance, and management staff per gross Megawatt (MW) capacity.

\section{Fuel Information}

This is used to help further describe plant operation by providing categorical divisions in data reporting. Most importantly, this information is used to relate the data by fuel types.

\section{Efficiency and Environmental Performance}

This section of the survey is the broadest and provides data on the following:

- Boiler efficiency.

- $\mathrm{SO}_{2}$ and $\mathrm{NO}_{\mathrm{x}}$ emissions as percent of permit per boiler.

- $\quad$ Calcium/Sulfur $(\mathrm{Ca} / \mathrm{S})$ ratio per boiler.

- $\quad$ Percent of ash used for beneficial purposes.

- Safety incidents during reported year.

\section{Research and Development}

This section seeks to gain industry perspective on the best direction for research and development of systems and components.

\section{Plant Operations}

Boiler availability and outages are broken down into forced and boiler related categories by the following:

- $\quad$ Percent of time boilers were available.

- $\quad$ Percent of outage hours that were forced.

- $\quad$ Percent of outage hours that were boiler related.

\section{RESULTING SURVEY DATA}

Overall, 2012 survey respondent percentage was low with only 21 stoker/PC boilers represented. To more effectively represent the industry, the percentage of survey respondents needs to rise significantly. However, the available data does provide some insight and is shown below. 


\section{Plant Information}

For reported 2012 data of stoker/PC boiler operation, the average number of full time operations staff per gross $\mathrm{MW}$ capacity was 0.38 , the average number of full time maintenance staff was higher at 0.52 , and the average number of full time management staff was lowest at 0.10 .

\section{Efficiency and Environmental Performance}

For stoker/PC boilers represented in the data, average efficiency was $88 \%$ during 2012. These same boilers operated at an average $\mathrm{Ca} / \mathrm{S}$ ratio of 1.6 , and $\mathrm{SO}_{2}$ emissions were $39 \%$ of permit per boiler while $\mathrm{NO}_{\mathrm{x}}$ emissions were $68 \%$. The two types of ash are individually recognized. During 2012, stoker/PC boilers used $15 \%$ of bottom ash and $12 \%$ of fly ash (per boiler) for beneficial purposes. Plant operation effects the environment as well as human wellbeing. During 2012, the number of man-days of lost time due to accident was 26 .

\section{Plant Operation}

Boiler availability describes the time that the boiler is operational, as opposed to the time that the boiler is not operational, and is divided by age of boiler. For boilers installed pre-1990, average availability was $89 \%$ of the total time while average availability for post-1990 boilers was slightly higher at $90 \%$. Outage hours, the time that a boiler is not available for operation, are distinguished by forced versus planned and boiler versus non-boiler related hours. For all reported stoker/PC boilers, the average number of outage hours that were forced, regardless of boiler age, was $37 \%$ (meaning $63 \%$ of boiler outage hours were planned). The average number of hours that were boiler related, also regardless of boiler age, was $80 \%$ (as opposed to $20 \%$ of outage hours that were caused by something other than a boiler).

\section{Breakdown of Outage Causes}

The specific causes of boiler outages are represented fully in Fig. (1). Here it is seen that combustor pressure and steam load parts played the biggest roles in outages. It is also noted that stoker technology causes a significantly higher percentage of outages than pulverizers.

\section{Concerns for Future Operation}

Looking forward to 2013 operation, boiler operators were asked to represent their concerns on a scale from 1 to 10 with 10 being the most worrisome. The data, shown in Fig. (2), shows that ash disposal and regulation is the greatest cause for concern going into year 2013 operation. Fuel quality and mechanical parts cause another large portion of concern going forward.

\section{Comparison to Past AFBC Benchmarks}

Important to the effective use of benchmarking is comparison of current performance to the performance of peers. The most recently available benchmark data within the coal fired electrical power generation industry is the 2011 report from WVU and CIBO [13]. This document provides a look at fluidized bed combustion industry data for the years 2006-2011.

Average AFBC boiler efficiency over the last five survey years is $85 \%$. This compares to a slightly higher stoker/PC boiler efficiency of $88 \%$. Average $\mathrm{Ca} / \mathrm{S}$ ratio for $\mathrm{AFBC}$ boilers was at 2.87 while reported stoker/PC boilers operated at a much lower ratio of 1.6. For AFBC boilers, the average number of full time non-management staff was 0.64 . This is lower than the average of the reported stoker/PC boilers at 0.9 staff per gross MW (adding together stoker/PC operations and maintenance staff). On the other hand, the average 0.13 management staff for AFBC was higher than the average stoker/PC management staff of 0.1 per gross MW.

Over the past 5 years, AFBC respondents have reported an average of 9.22 man-days of lost time due to accident. In 2012, stoker/PC respondents reported an average of 26 days of lost time. On average, AFBC boilers have been available $90 \%$ of the time while, over the past year, stoker/PC boilers had a similar availability of $89 \%$. For AFBC boilers, $33 \%$ of

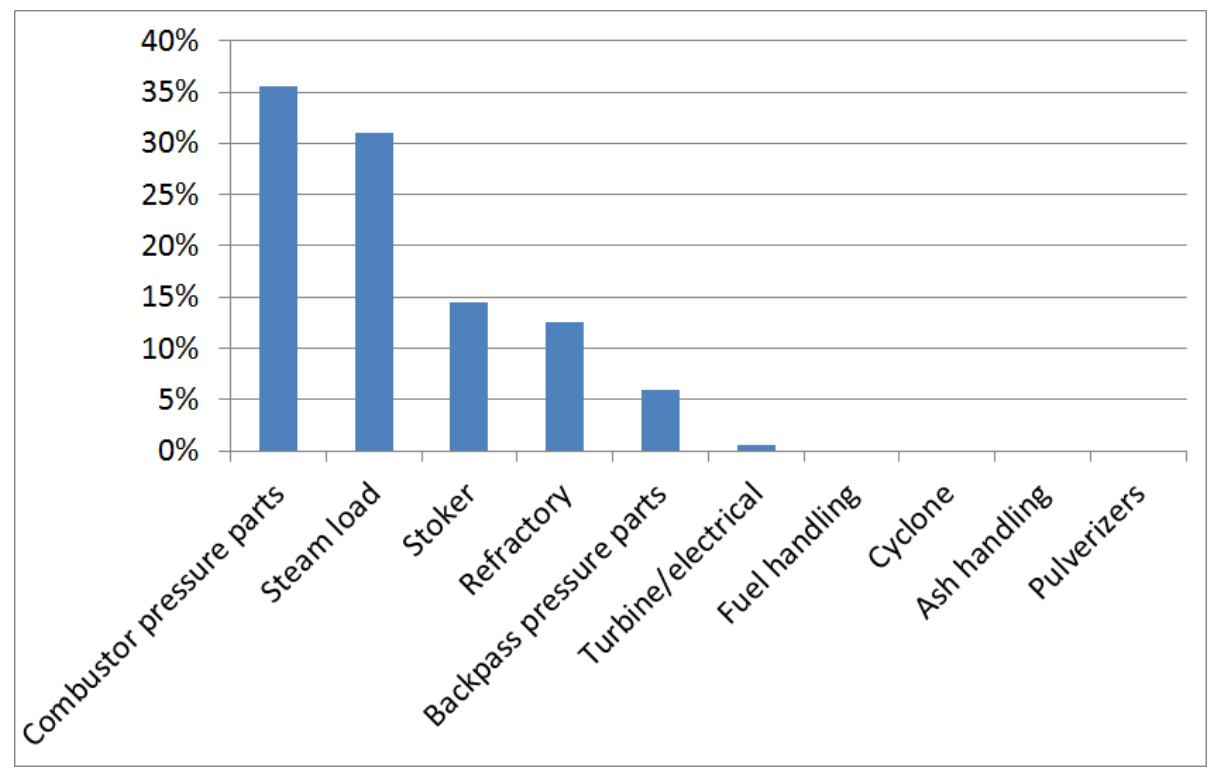

Fig. (1). 2012 forced outage causes of stoker/PC boilers. 


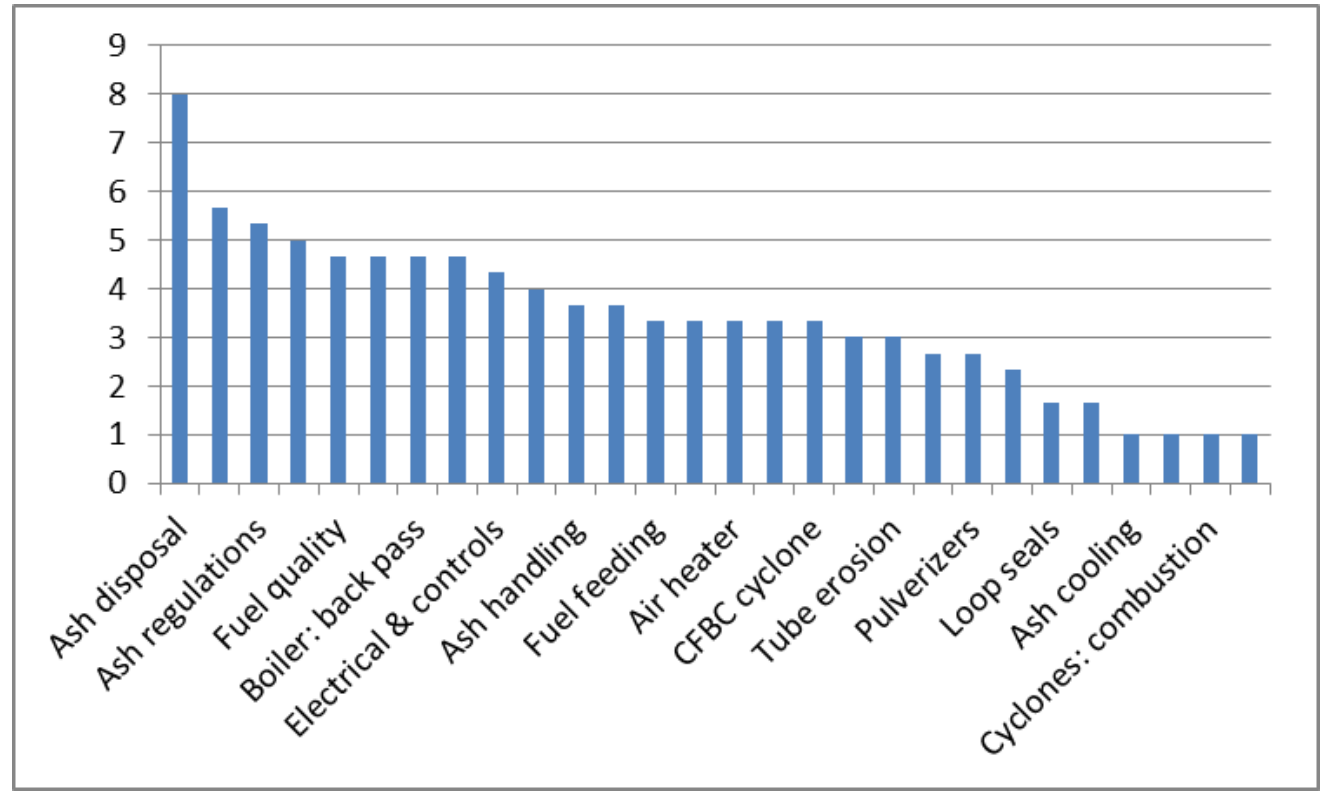

Fig. (2). Boiler O/M concerns for stoker/PC 2013 operation.

those outage hours were forced and $89 \%$ were boiler related. Comparing to stoker/PC boilers, $37 \%$ were forced and $80 \%$ were boiler related.

All of these results are summarized below in Fig. (3). For results that are not naturally produced as percentages, the data are normalized by the maximum value of the two being compared. This includes the $\mathrm{Ca} / \mathrm{S}$ ratio and the staff per gross MW sections.

\section{CONCLUSION}

Given the small- and large-scale impact that the coal industry has on day to day life around the world, it is paramount that continued efforts are made to advance the art of burning coal to generate electrical power. One way to do this is identifying existing strengths and weaknesses through benchmarking. The benchmark method shown above is limited by the amount of data received via survey respondents. Without adequate data, conclusions can only be drawn conservatively. Further, because this is the first year of data gathered for the stoker/PC industry, changes over time within this specific industry are not yet available. Despite these limitations, the reported results are of interest and provides a starting point for the future of the study.

The availability of AFBC industry data does provide a comparison point. From the data, it seems that stoker/PC

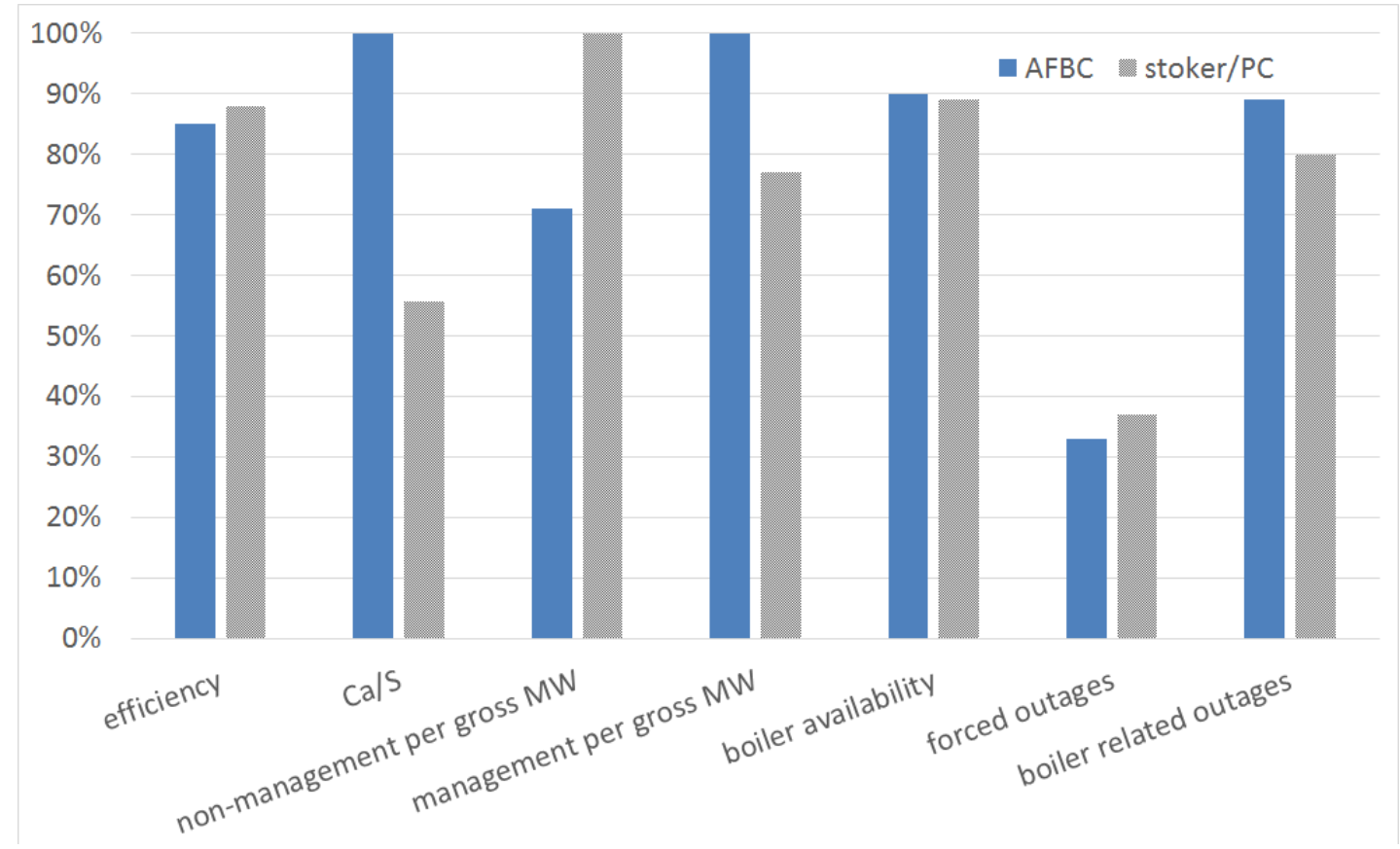

Fig. (3). Summary of comparison between AFBC and stoker/PC boiler findings. 
boilers operate at a lower $\mathrm{Ca} / \mathrm{S}$ ratio, a slightly higher efficiency, and require more non-management staff. These statements are dependent on the nature of the survey respondents, and in the future, it is desired that a greater number of survey respondents be achieved.

\section{CONFLICT OF INTEREST}

The authors confirm that this article content has no conflict of interest.

\section{ACKNOWLEDGEMENTS}

Declared none.

\section{REFERENCES}

Annual Energy Outlook 2014 Early Release Overview. (2013, December 16) Available: http://www.eia.gov/forecasts/aeo/er/inde X.cfm

[2] U. S. E. I. Administration. (2012, May 7, 2014). Projected retirements of coal-fired power plants. Available: http://www.eia. gov/todayinenergy/detail.cfm?id $=7330$

[3] J. A. Fuller and M. Robinson, "Realizing Performance and Emissions Goals through Benchmarking the Fluidized Bed Industry," West Virginia University, Journal entry: to be accepted 2013.

[4] J. A. Fuller and L. S. Ayre, "Performance Enhancements for the Reduced Environmental Impact of Atmospheric Fluidized Bed
Combustion Plants," The Journal of Energy and Development, vol. 34, pp. 253-263, 2011.

[5] "Available and Emerging Technologies for Reducing Greenhouse Gas Emissions From Coal-Fired Electric Generating Units," O. o. A. a. Radiation, Ed., ed. Research Triangle Park, North Carolina: U.S. Environmental Protection Agency, 2010.

[6] J. McMullan, B. Williams, and E. Sloan, "Clean coal technologies," Proceedings of the Institution of Mechanical Engineers Part aJournal of Power and Energy, vol. 211, pp. 95-107, 1997.

[7] U. S. EPA. (2014, February 20). Bottom Ash. Available: http://www.epa.gov/osw/conserve/imr/ccps/bottomash.htm

[8] U. S. EPA. (2014, February 20). Fly Ash. Available: http://www. epa.gov/osw/conserve/imr/ccps/flyash.htm

[9] $\mathrm{SO}_{2}$ and $\mathrm{NO}_{\mathrm{x}}$ EMissions, Compliance, and Market Analyses Report," Progress Report 2011 ed: U.S. Environmental Protection Agency, 2011.

[10] J. E. McCarthy, "EPA Standards for Greenhouse Gas Emissions from Power Plants: Many Questions, Some Answers ", ed: Congressional Research Service, 2013.

[11] U. S. EPA. (2014, February 21). Regulatory Actions - Final Mercury and Air Toxics Standards (MATS) for Power Plants. Available: http://www.epa.gov/mats/actions.html

[12] D. Adebanjo, A. Abbas, and R. Mann, "An investigation of the adoption and implementation of benchmarking," International Journal of Operations \& Production Management, vol. 30, pp. 1140-1169, 2010.

[13] J. A. Fuller and M. Robinson, "Fluidized Bed Industry Benchmarking: A Five-Year Review," West Virginia University, Journal entry: to be accepted 2013 .

(C) Fuller and Robinson; Licensee Bentham Open.

This is an open access article licensed under the terms of the Creative Commons Attribution Non-Commercial License (http://creativecommons.org/licenses/bync/3.0/) which permits unrestricted, non-commercial use, distribution and reproduction in any medium, provided the work is properly cited. 